\section{Biology Teaching and Learning}

\section{ISSN 2621 - 5527}

Abstract. This research is praexperimental design that aims to determine effectiveness of student"s learning interest and outcomes toward learning strategies based humor on genetic subject of student grade XII SMA Negeri 11 Makassar. Independent Variabe in this research is the application of learning strategies based humor on genetic subject, while the dependent variable is the student"s learning interest and outcomes of genetic subject. The population in this study were all students of class XII SMA Negeri 11 Makassar with totally seven classes, while the sample is student"s grade XII with totally 66 students. Pretest-posstest was used as data collection technique, by used a questionnaire of student learning interest and genetic achivement test. Data analysis technique that used is a descriptive analysis using the n-gain and inferential analysis using paired sample ttest. Based on the descriptive analysis showed that n-gain value of student"s interest and learning outcomes of genetics achieve an increase of $>75 \%$ in the category of medium-high, which are respectively $77 \%$ and $92 \%$, whereas the inferential analysis using SPSS showed a significance value $0.000>\alpha=0.05$ which indicates $\mathrm{H}_{0}$ is rejected and $\mathrm{H}_{1}$ is accepted, that the known application learning strategies based humor on genetic subject has a significant influence (real) towards the student"s learning interests and outcomes. Therefore, based on these two data analysis concluded that the learning strategies based humor on genetic subject effectively to student"s learning interest and outcomes of student of grade XII SMA Negeri 11 Makassar.

Keywords: learning strategies based humor, student's interest, student outcomes, genetic.

Suci Ramdani Fitri Universitas Negeri Makassar Indonesia

Hamka L. Universitas Negeri Makassar Indonesia

Sitti Saenab Universitas Negeri Makassar Indonesia

\section{Keefektifan Penerapan Strategi Pembelajaran Berbasis Humor Pada Materi Genetika Terhadap Minat dan Hasil Belajar Siswa Kelas XII SMA Negeri 11 Makassar}

\author{
Suci Ramdani Fitri \\ Hamka L. \\ Sitti Saenab
}

Abstrak. Penelitian ini merupakan penelitian pre-eksperimen yang bertujuan untuk mengetahui keefektifan penerapan strategi pembelajaran berbasis humor pada materi genetika terhadap minat dan hasil belajar siswa kelas XII SMA Negeri 11 Makassar. Variabe bebas pada penelitian ini adalah penerapan strategi pembelajaran berbasis humor, sedangkan variable terikatnya adalah minat dan hasil siswa pada materi genetika. Populasi dalam penelitian ini adalah seluruh siswa kelas XII SMA Negeri 11 Makassar, dengan jumlah sampel 66 orang. Instrumen penelitian yang digunakan berupa angket minat belajar dengan skala likert dan tes hasil belajar genetika. Teknik analisis data yang digunakan yaitu analisis statistik deskriptif menggunakan n-gain dan analisis statistik inferensial menggunakan paired sample t-test (Uji-t berpasangan). Berdasarkan analisis statistik deskriptif diperoleh bahwa nilai n-gain untuk minat maupun hasil belajar genetika siswa mencapai peningkatan $>75 \%$ pada katagori sedang-tinggi yakni minat belajar sebesar 77\% dan hasil belajar mencapai 92\%, sedangkan pada analisis statistik inferensial menggunakan SPSS 16.00 diperoleh nilai signifikansi $0.000>\alpha=0.05$ yang menunjukkan $H_{1}$ diterima, yakni penerapan startegi pembelajarn berbasis humor berpengaruh secara signifikan (nyata) terhadap minat dan hasil belajar siswa. Berdasarkan dua analisis data tersebut disimpulkan bahwa penerapan strategi pembelajaran berbasis humor pada materi genetika efektif terhadap minat belajar dan hasil belajar siswa kelas XII SMA Negeri 11 Makassar.

Kata Kunci: strategi pembelajaran berbasis humor, minat belajar, hasil belajar, genetika.

\section{Pendahuluan}

Proses pembelajaran yang efektif sudah tentu melibatkan kemampuan guru untuk mendemonstrasikan suatu keterampilan sedemikian rupa sehingga para siswa dapat memahami dan terlibat langsung dalam proses pembelajaran. Berdasarkan Handbook of Research on Teaching, C.M. Clark \& Peterson (1984) menyimpulkan bahwa setidaknya guru harus membuat keputusan yang penting dalam mengajar setiap 2 menit sekali. Setiap pengambilan keputusan tersebut haruslah didasarkan pada kondisi pembelajaran yang berlangsung sehingga diharapkan keputusan tersebut dapat berdampak signifikan terhadap proses pembelajaran, perkembangan dan pencapaian kesusksesan jangka panjang siswa. Salah satu konsep biologi yang dianggap sulit dan menuntut guru untuk cerdas menentukan dan merancang strategi khusus adalah Genetika.

Fakta ini di dukung oleh penelitian Suparyana (2014) terhadap penguasaan materi siswa kelas XII di Kabupaten Bandung Barat dan Kabupaten Tasikmalaya yang menunjukkan penguasaan konsep seluruh siswa pada materi genetika berada dalam kategori rendah yakni sebesar (49.93\%). Sedangkan penelitian Tekkaya, dkk (2001) 
menjelaskan bahwa dari 31 konsep pada mata pelajaran biologi SMA lebih dari 36\% siswa merasa sulit untuk mempelajari konsep mengenai gen, allel, kromosom, kromatin, kromatid, serta konsep pembelahan sel mitosis dan meiosis. Suparyana (2014) dan Haambokoma (2007) menjelaskan bahwa kesulitan belajar siswa pada konsep genetika disebabkan oleh istilah-istilah baru yang sulit mereka mengerti, bahasa buku yang abstrak, guru yang kurang profesional dalam menyajikan materi sehingga konsep tidak tersampaikan dengan benar.

Hal-hal seperti ini akhirnya membentuk pola pikir siswa bahwa genetika itu sulit, serta apabila guru melakukan pola pembelajaran yang membosankan hal ini akhirnya menyebabkan siswa kehilangan minat untuk mempelajari genetika lebih lanjut. Minat merupakan salah satu aspek psikologis yang mempengaruhi kualitas pencapaian hasil belajar siswa. Menurut Hilgard dalam slameto (2010) Minat adalah suatu rasa lebih suka dan rasa keterkaitan pada suatu hal atau aktivitas, tanpa ada yang menyuruh. Minat pada dasarnya adalah penerimaan akan sesuatu diluar diri. Semakin kuat atau dekat hubungan tersebut semakin besar minat.

Penggunaan humor merupakan salah satu strategi pembelajaran yang dapat menciptakan suasana menyenangkan dan dapat diterapkan oleh guru. Sheinowitz (1996, dalam Darmansyah, 2010) membagi rancangan humor untuk pembelajaran ke dalam dua jenis, yaitu (1) unplanned humor, dan (2) planned humor. Penggunaan humor dalam proses pembelajaran dapat dilakukan oleh guru dengan menggunakan sisipan kata-kata, bahasa, gambar, anekdot, cerita singkat, kartun, karikatur, peristiwa sosial, pengalaman hidup, lelucon atau plesetan yang dapat merangsang terciptanya suasana riang, rileks dan menyenangkan dalam pembelajaran yang mampu menggelitik siswa untuk tertawa (Darmansyah, 2010).

Humor sebagai strategi mengajar, memiliki empat manfaat dalam pembelajaran yaitu (1) membangun hubungan dan meningkatkan komunikasi antara guru dan peserta didik,(2)mengurangi stress, (3) membuat pembelajaran menjadi menarik, (4) meningkatkan daya ingat pada suatu materi pelajaran.. Sebelumnya Saenab,dkk (2015) telah melakukan penelitian untuk melihat sejauh mana ketertarikan siswa kelas XII SMA Negeri 11 Makassar jika strategi pembelajaran berbasis humor diterapkan pada proses pembelajaran mereka, dan berdasarkan data yang diperoleh sebanyak 49 siswa $(81,75 \%)$ memiliki rasa tertarik yang tinggi, sebanyak 5 siswa (9.25\%) dalam katagori sedang dan (0\%) pada katagori rendah. Hal ini menunjukkan bahwa sebagian besar siswa mengiginkan staregi pembelajaran berbasis humor untuk diterapkan, begitu pula pada respon yang mereka berikan bahwa mereka merasa lebih betah dan senang dalam mengikuti pelajaran. Penerapan strategi pembelajaran berbasis humor secara terencana (planned humor) pada materi genetika diharapkan dapat meningkatkan minat siswa kelas XII SMA Negeri Makassar, oleh sebab it penelitian ini dimaksudkan untuk mengetahui apakah strategi pembelajaran berbasis humor efektif terhadap minat hasil belajar siswa kelas XII SMA Negeri Makassar.

\section{Metode Penelitian}

Penelitian ini merupakan penelitian praeksperimen (Campbell and Stanley, 1966). Penelitian ini dilaksanakan pada semester ganjil tahun Ajaran 2016/2017 di SMAN 11 Makassar, dengan jumlah sampel sebanyak 66 siswa kelas XII. Desain penelitian yang digunakan adalah one-group pretest-posttest.

\section{$01 \times 02$}

\section{Gambar 1. Desain Penelitian One-Group Pretest - Posttest}

\section{Ket: $\quad \mathrm{X} \quad$ : Perlakuan menggunakan strategi pembelajaran berbasis humor \\ 01 : Pretest \\ 02 : Posttest}

Instrumen penelitian yang digunakan pada penelitian ini yaitu: Angket minat belajar menggunakan skala likert dan instrument tes hasil belajar berupa tes objektif bentuk pilihan ganda (multiple choice item test) pada materi genetika dalam ranah kognitif yang meliputi aspek pengetahuan, pemahaman, dan aplikasi. 
Analisis data yang digunakan adalah analisis statistik deskriptif yang meliputi nilai rata-rata (mean), nilai tertinggi (maksimum), dan nilai terendah (minimum) dengan menggunakan sistem (SPSS) versi 16.0, serta analisis statisik inferensial menggunakan uji-t sample berpasangan. Sedangkan penggunaan gain ternormalisasi dimaksudkan untuk melihat seberapa besar peningkatan hasil belajar siswa dari pretest ke postest.

\begin{tabular}{|l|}
\hline (Nilai Post test - Nilai Pre test $)$ \\
\hline$n$-gain $=($ Nilai Maksismum - Nilai Pre test $)$ \\
\hline
\end{tabular}

Gambar 2. Rumus N-gain.

Nilai $n$-gain hasil belajar selanjutnya dikatagorikan dengan kriteria sebagai berikut:

Tabel 1. Kategori Tingkat N-gain.

\begin{tabular}{|l|c|}
\hline \multicolumn{1}{|c|}{ Nilai N-gain } & Kategori \\
\hline $\mathbf{g} \geq \mathbf{0 , 7}$ & Tinggi \\
\hline $\mathbf{0 , 7}>\mathbf{g} \geq \mathbf{0 , 3}$ & Sedang \\
\hline $\mathbf{g}<\mathbf{0 , 3}$ & Rendah \\
\hline
\end{tabular}

Sumber: Meltzer (2002).

Selanjutnya mengacu pada kedua analisis data diatas penerapan strategi pembelajaran berbasis humor dikatakan efektif jika a) terdapat $>75 \%$ dari jumlah siswa memperoleh nilai (ngain) minat/hasil belajar pada katagori sedang dan/atau tinggi; b) Secara statistika, minat/hasil belajar siswa menunjukkan perbedaan yang signifikan antara sebelum dan setelah pembelajaran pada uji paired sample t-test.

\section{Hasil dan Pembahasan}

Minat belajar siswa diukur menggunakan angket menggunakan skala likert yang terdiri dari lima pilihan, yaitu sangat setuju, setuju, netral, tidak setuju, dan sangat tidak setuju. Parrot (1994, dalam Shiyab, 2008) menegaskan bahwa humor dapat digunakan sebagai strategi mengajar, humor dapat meningkatkan pemahaman serta meningkatkan perhatian dan minat siswa. Adapun deskripsi minat belajar siswa sebelum dan sesudah diajar menggunakan strategi pembelajaran berbasis humor dapat dilihat pada Tabel 2.

Tabel 2. Deskripsi Nilai Pretest dan Posttest Minat Belajar Siswa.

\begin{tabular}{|c|c|c|}
\hline \multirow{2}{*}{ Statistik } & \multicolumn{2}{|c|}{ Nilai } \\
\cline { 2 - 3 } & Pretest & Posttest \\
\hline Jumlah sampel & 66 & 66 \\
\hline Nilai terendah & 21 & 69 \\
\hline Nilai tertinggi & 79 & 100 \\
\hline Mean & 59.86 & 80,07 \\
\hline Median & 61,5 & 79 \\
\hline Modus & 64 & 75 \\
\hline Standar deviasi & 13,7 & 7,47 \\
\hline
\end{tabular}

Berdasarkan data pretest minat belajar siswa, diketahui terdapat peningkatan minat belajar siswa, sebanyak 66 siswa sampel memiliki nilai rata-rata (mean) pretest 59,68 dengan rentan sebaran data (standar deviasi) mencapai 13,7. Sementara rata-rata minat belajar siswa setelah dibelajarkan menggunakan strategi pembelajaran berbasis humor (posttest) meningkat menjadi 80,07, dengan standar deviasi sebesar 7,47. 


\section{Tabel 3. Distribusi Frekuensi dan Persentase Kategori Nilai Pretest dan Posttest Minat} Belajar Siswa

\begin{tabular}{|c|c|c|c|c|}
\hline \multirow{2}{*}{ Kategori } & \multicolumn{2}{|c|}{ Pretest } & \multicolumn{2}{c|}{ Posttest } \\
\cline { 2 - 5 } & F & P (\%) & F & P (\%) \\
\hline Sangat Tinggi & 0 & 0 & 15 & 22,73 \\
\hline Tinggi & 14 & 21,2 & 49 & 74,24 \\
\hline Sedang & 33 & 50,0 & 2 & 3,03 \\
\hline Rendah & 14 & 21,2 & 0 & 0 \\
\hline Sangat Rendah & 5 & 7,6 & 0 & 0 \\
\hline
\end{tabular}

Berdasarkan Tabel 3. menunjukkan distribusi frekuensi dan presentase nilai pretest dan posttest minat belajar siswa dalam kategori sangat tinggi, tinggi, sedang, rendah, dan sangat rendah. Diketahui minat belajar siswa sebelum dibelajarkan mengunakan strategi humor sebagian besar berada pada katagori sedang ke bawah, yakni total sebesar 77,9\% berada pada pada katagori sedang, rendah dan sangat rendah, sedangkan untuk katagori tinggi hanya $21.2 \%$ dan katagori sangat tinggi $0 \%$. Namun, setelah dibelajarakan menggunakan startegi berbasis humor sebagian besar minat belajar siswa berada pada katagori tinggi yakni sebesar $74,24 \%$, dan juga pada katagori sangat tinggi yang mencapai $22,73 \%$ dan hanya 3,01\% siswa yang berada pada katagori sedang sedangkan pada katagori rendah dan sangat rendah $0 \%$.

Dilihat dari rata-rata minat belajar siswa sebelum dan sesudah diajar menggunakan strategi pembelajaran berbasis humor diketahui bahwa penerapan strategi humor dapat menigkatkan minat belajar siswa. Civikly (1986, dalam Shiyab, 2008) telah menunjukkan bahwa humor dapat meningkatkan minat siswa dalam belajar. Hal ini juga dapat mengurangi stres siswa dan meningkatkan rasa percaya diri. Pada umumnya humor yang disajikan tidak lepas dari gelak tawa sebagai efek serta suatu ekspresi singkat.

Ditinjau dari sudut psikologi tertawa merupakan bentuk pelepasan kegelisahan yang tertimbun sebagai hasil dari aktivitas sebelumnya. Adapun perangkat pembelajaran berbasis humor yang digunakan dalam penelitian ini yakni perangkat yang menyisipkan kata-kata lucu, karikatur dan kartun yang akan membuat suasana pembelajaran yang menyenangkan bagi siswa. Contohnya seperti penciptaan karakter keluarga Geni (Gen masa kini) yang diilustrasikan layaknya sebuah karikatur keluarga berbentuk DNA double helix dengan nama penokohan pak Genito, Bu Genita, dan anaknya Geni dan Geno. Selain itu, ditampilkan pula variasi jengger ayam sebagai bentuk penyimpangan semu hukum mendel dalam bentuk "Tren pial ayam 2016" yang diilustrasikan menyerupai model pilihan gaya rambut bagi ayam. Hal ini tentunya menarik perhatian dan minat siswa untuk lebih tertarik selama proses pembelajaran.

Analisis data yang juga digunakan untuk melihat seberapa besar perubahan yang ditimbulkan dari penerapan strategi pembelajaran berbasis humor terhadap hasil belajar siswa pada materi genetika adalah uji gain ternormalisasi (n-gain). Berdasarkan nilai $n$-gain yang diperoleh masingmasing siswa, nilai tersebut dikelompokkan dalan 3 katagori yakni tinggi, sedang dan rendah.

Berikut adalah distribusi frekuensi dan persentase nilai $n$-gain minat belajar siswa setelah diajar menggunakan strategi pembelajaran berbasis humor dapat dilihat pada gambar 3.

\section{Nilain-gainMinat Belajar \\ $\square$ Tinggi $\square^{\text {Sedang }}{ }^{\circ}$ Rendah}

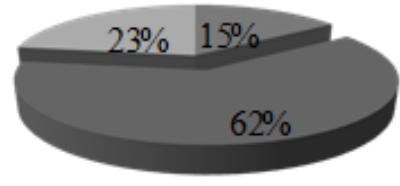


Peningkatan minat belajar selanjutnya juga dibuktikan melalui analisis statistik deskriptif menggunakan n-gain ternormalisasi yakni pada katagori tinggi sebanyak 10 siswa (15\%), pada katagori sedang 41 siswa (62\%) dan pada katagori rendah 15 siswa (29\%).

Berdasarkan data nilai $n$-gain tersebut, diketahui bahwa peningkatan minat belajar siswa yang berada pada katagori sedang dan tinggi mencapai 51 siswa atau (77\%). Uji statistik inferensial menggunakan uji-t sampel berpasangan juga menunjukkan nilai signifikansi 0.000 yang berarti terdapat perbedaan signifikan (nyata) antara sebelum dan sesudah proses pembelajaran. Sehingga diketahui bahwa peningkatan minat belajar siswa telah memenuhi indikator keberhasilan. Oleh sebab itu penerapan strategi pembelajaran berbasis humor pada materi genetika efektif terhadap minat belajar siswa pada materi genetika.

Hamalik (2008), menyatakan bahwa belajar tanpa adanya minat (motivasi) kiranya sulit untuk mencapai keberhasilan secara optimal. Oleh sebab itu setelah mengetahui bahwa strategi pembelajaran berbasis humor berpengaruh positif terhadap peningkatan minat belajar siswa, selanjutnya diharapkan pula dapat berpengaruh terhadap peningkatan hasil belajar siswa. Hasil belajar merupakan salah satu faktor penentu yang menunjukkan bahwa seorang siswa memahami pelajaran yang diberikan atau tidak.

Deskripsi pretest, posttest dan n-gain hasil belajar genetika siswa yang diajar menggunakan strategi pembelajaran berbasis humor dapat dilihat pada Tabel 4 .

Tabel 4. Deskripsi Pretest dan Posttest Hasil Belajar Genetika Siswa

\begin{tabular}{|c|c|c|}
\hline \multirow{2}{*}{ Statistik } & \multicolumn{2}{|c|}{ Nilai } \\
\cline { 2 - 3 } & Pretest & Posttest \\
\hline Jumlah sampel & 66 & 66 \\
\hline Nilai terendah & 13 & 27 \\
\hline Nilai tertinggi & 47 & 87 \\
\hline Mean & 25,42 & 62,43 \\
\hline Median & 27 & 67 \\
\hline Modus & 27 & 67 \\
\hline Standar deviasi & 7,66 & 11,29 \\
\hline
\end{tabular}

Setelah mengetahui kemampuan awal siswa, melalui pretest yang diberikan, selanjutkan dilakukan analisis hasil belajar siswa setelah dibelajarkan menggunkan strategi pembelajaran berbasis humor (posttest). Seperti tampak pada tabel 5 mengenai distribusi hasil belajar siswa diketahui rata-rata hasil belajar siswa (posttest) adalah 62.43, dengan rincian pada katagori sangat tinggi sebanyak 1 siswa (2\%), katagori tinggi 19 siswa (29\%), katagori cukup 32 siswa (48\%), katagori rendah 12 siswa (18\%) dan katagori sangat rendah 2 siswa (3\%). Sehingga diketahui bahwa rentan nilai sebagian besar siswa berada pada karagori cukup ke tinggi.

Tabel 5. Distribusi Frekuensi dan Persentase

\begin{tabular}{|c|c|c|c|c|}
\hline \multirow{2}{*}{ Kategori } & \multicolumn{2}{|c|}{ Pretest } & \multicolumn{2}{c|}{ Posttest } \\
\cline { 2 - 5 } & F & $\begin{array}{c}\text { P } \\
\text { (\%) }\end{array}$ & F & $\begin{array}{c}\text { P } \\
\text { (\%) }\end{array}$ \\
\hline Sangat Tinggi & - & - & 1 & 2 \\
\hline Tinggi & - & - & 19 & 29 \\
\hline Sedang & - & - & 32 & 48 \\
\hline Rendah & 3 & 5 & 12 & 18 \\
\hline Sangat Rendah & 63 & 95 & 2 & 3 \\
\hline
\end{tabular}

Kategori Nilai Pretest dan Posttest Hasil Belajar Siswa

Peningkatan hasil belajar yang ditunjukkan siswa berdasarkan nilai pretest dan posttest dapat ditunjang dari berbagai faktor, salah satunya adalah faktor internal yakni peningkatan 
(hlm. 1-8)

minat belajar siswa. Seperti yang tampak selama proses pembelajaran siswa tampak terbantu dengan penggunaan konten humor seperti gambar-gambar lucu terkait materi genetika, yang secara tidak langsung menimbulkan rasa santai dan senang selama proses pembelajaran. Mereka juga tampak tidak sengan untuk langsung mengajukan pertanyaan saat mereka mulai penasaran mengenai suatu konsep, dan hal ini sangat berpengaruh positif terhadap suasana belajar di dalam kelas. Selain itu, melalui penayangan gambar-gambar lucu disetiap jeda pembelajaran terbukti mempermudah guru untuk mengambil kembali perhatian seluruh siswa di dalam kelas untuk kembali memperhatikan atau sekedar menghentikan aktivitas individu siswa diluar kegiatan pembelajaran.

Berikut adalah gambar persentase katagorisasi nilai n-gain.

Nilai n-gain Hasil Belajar Siswa

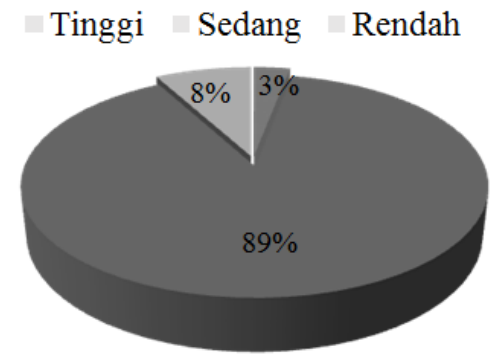

\section{Gambar 4. Persentase Nilai N-gain Hasil Belajar}

Uji n-gain Ternormalisasi untuk tes hasil belajar menunjukkan lebih dari 75\% dari jumlah siswa mengalami peningkatan (kearah positif) yakni peningkatan nilai $n$-gain pada katagori sedang dan tinggi dengan total (92\%), serta uji-t sampel berpasangan hasil belajar siswa juga menunjukkan nilai signifikansi 0.000 yang berarti terdapat perbedaan hasil belajar yang signifikan (nyata) antara sebelum dan sesudah proses pembelajaran. Oleh sebab itu dapat dikatakan bahwa penerapan strategi pembelajaran berbasis humor pada materi genetika efektif terhadap hasil belajar siswa.

Parrot (1994, dalam Shiyab, 2008) menegaskan bahwa humor dapat digunakan sebagai strategi mengajar, humor dapat meningkatkan pemahaman serta meningkatkan perhatian dan minat siswa. Hal ini didukung oleh pernyataan Deiter (2000) bahwa alasan utama penggunaan strategi humor ini adalah untuk meningkatkan hasil belajar siswa dan tentunya untuk mencapai tujuan pembelajaran.

Pengalaman tersebut berkesesuaian dengan penelitian survei yang dilakukan Abaudan (2012) terkait mengapa siswa mengiginkan humor dalam proses pembelajarannya, sebanyak 79\%:21\% siswa setuju bahwa humor dapat menguragi hambatan komunikasi antara guru dan siswa, 71\% berpendapat bahwa humor mengurangi rasa takut dan sungkan pada guru mereka dan 88\% mengatakan bahwa humor membuat lingkungan belajar mereka lebih menyenangkan. Pemberian humor diyakini membantu siswa untuk mengingat kembali saat ujian. Schmidt (2002, dalam Banas.dkk, 2011) menyatakan "when context is held constant, humorous information is recalled more easily than nonhumorous information", yang artinya, ketika konteks atau perlakukan diberikan secara konstan, informasi humoris diingat lebih mudah daripada informasi non humor.

Namun, pada kenyataannya tidak semua konten materi genetika dapat diintegrasikan dengan humor agar mudah diigat atau dipahami. Hal tersebut yang menjadi kekurangan pada penelitian ini, bahwa humor yang disisipkan dirasa kurang maksimal untuk membantu siswa memahami seluruh materi genetika pada tingkat SMA, selain itu alokasi waktu pertemuan genetika yang hanya 8 kali tatap muka selama 4 minggu, juga membuat guru harus cermat memakai waktu untuk berhumor agar kegiatan seperti diskusi kelompok dapat dimaksimalkan.

Alokasi waktu efektif pembelajaran genetika pada proses penelitian kurang lebih hanya 31 menit setiap pertemuan bagi guru untuk menyajikan materi pembelajaran dengan menyisipkan konten humor, selebihnya terdapat 57 menit waktu yang dialokasikan untuk kegiatan penugasan 
dan diskusi kelompok. Hal ini pula yang mempengaruhi pemilihan konten humor pada penelitian ini terbatas hanya pada gambar karakter dan karikatur lucu dengan visualisai percakapan atau dialog, peneliti memutuskan tidak menggunakan video lucu dalam strategi karena mempertimbangkan waktu yang tersedia, karena penayangan video pasti memerlukan alokasi waktu tersendiri, serta setelah penayangan guru membutuhkan waktu tambahan untuk menjelaskan kembali apa maksud dari video tersebut. Oleh sebab itu, bagi peneliti selanjutnya diharapkan dapat dapat memilih dan merancang lebih banyak variasi humor yang tentunya efektif dengan ketersediaan waktu pembelajaran biologi.

\section{Kesimpulan}

Berdasarkan analisis data dan pembahasan hasil penelitian yang telah dilakukan, maka dapat disimpulkan:

1. Penerapan strategi pembelajaran berbasis humor pada materi genetika efektif terhadap minat belajar siswa kelas XII SMA Negeri 11 Makassar.

2. Penerapan strategi pembelajaran berbasis humor pada materi genetika efektif terhadap hasil belajar siswa kelas XII SMA Negeri 11 Makassar.

\section{Referensi}

Aboudan, Rima. (2009). Laugh and Learn: Humor and Learning a Second Language. International Journal of Arts and Sciences. 3 (3): 90 - 99-CD-ROM. ISSN: 1944-6934. United Arab Emirates University, United Arab Emirates.

Bannas, J. A. Dunbar, N. Rodriguez, D. \& Liu, Shr-Jie. 2011 "A Review of Humor in Educational Settings: Four Decades of Researc", Journal of Communication Education. 60 (1), 115_144. Routledge:Taylor and Francis Group.

Campbell, D.T., \& Julian C.S. (1996). "Experimental and Quasi experimental Designs for Research". USA : Houghton Mifflin Company

Clark, Christopher M. \& Penelope, L. Peterson. (1984). "Theacher's Thought Processes". Michigan : Michigan State University.

Darmansyah. (2010). Strategi Pembelajaran Menyenangkan dengan Humor. Bumi Aksara. Jakarta.

Deiter, Ron. (2000). The Use of Humor as a Teaching Tool in the College Classroom. NACTA Journal, June. https://www.econ.iastate.edu/.../p4506-2000-06. Makasssar. Diakses 19 Februari 2015.

Haambokoma, Christopher. (2007). “ Nature and Causes of Learning in Genetic at High School Level in Zambia." Journal of International Development and Cooperation. 13 (1), 1-9. University of Zambia: Lusaka, Zambia.

Hamalik, Oemar. (2008). “Proses Belajar Mengajar”. Bumi Aksara: Jakarta.

Meltzer, David E. (2002). "The relationship between mathematics preparation and conceptual Learning gains in physics: a possible ",, hidden variable "' in diagnostic Pretest scores". Jurnal American Association of Physics Teachers diakses melalui http://ojps.aip.org/ajp/ pada 3 April 2016. 
(hlm. 1-8)

Saenab, Sitti. Nurhayati. L, Hamka. (2015). “ Minat Siswa Kelas XII SMAN 11 Makassar Terhadap Strategi Pembelajaran Berbasis Humor". Prosiding, ISSN : 2460-1322. Seminar Nasional 2015 Lembaga Penelitian UNM.

Slameto. (2010). "Belajar dan Faktor-Faktor yang Mempengaruhinya". Jakarta : Rhinneke Cipta.

Suparyana, D. Firman. (2014). "Analisis Penguasaan Konsep dan Miskonsepsi Siswa SMA pada Materi Genetika". Tesis . Bandung : Universitas Pendidikan Indonesia.

\begin{tabular}{|l|l|}
\hline Suci Ramdani Fitri & $\begin{array}{l}\text { S,Pd. Jurusan Biologi FMIPA UNM, Universitas Negeri Makassar. } \\
\text { Email: } \underline{\text { suciramdanifitri.edu@gmail.com }}\end{array}$ \\
\hline Hamka L. & $\begin{array}{l}\text { Drs, M,Si. Dosen. Jurusan Biologi FMIPA UNM, Universitas Negeri } \\
\text { Makassar. } \\
\text { Email: } \underline{\text { hamka.l biounm@yahoo.com }}\end{array}$ \\
\hline Sitti Saenab & $\begin{array}{l}\text { SP,d, M,Pd. Dosen. Jurusan Biologi FMIPA UNM, Universitas Negeri } \\
\text { Makassar. } \\
\text { Email: } \underline{\text { saenabsitti@gmail.com }}\end{array}$ \\
\hline
\end{tabular}

